\title{
Degradable Polymers Prepared from Alkyl Sorbates and Oxygen Under Atmospheric Conditions and Precise Evaluation of their Thermal Properties
}

\author{
Hiromichi HataKenaKa, Yoji TAKAhashi, and Akikazu Matsumoto ${ }^{\dagger}$ \\ Department of Applied Chemistry, Graduate School of Engineering, Osaka City University, \\ Sugimoto, Sumiyoshi-ku, Osaka 558-8585, Japan
}

(Received April 3, 2003; Accepted June 21, 2003)

\begin{abstract}
We report here the alternating copolymers of diene monomers with oxygen as a new class of degradable polymer with great potential. The alternating copolymers of alkyl sorbates with oxygen are efficiently prepared without decomposition under atmospheric conditions in the presence of an azo initiator. The produced alternating copolymers exothermically decompose upon heating in a similar mechanism irrespective of the kind of the ester alkyl group of the sorbates; i.e., the methyl, ethyl, octadecyl, and trifluoroethyl esters. The initial and maximum decomposition temperatures $\left(T_{\text {init }}\right.$ and $\left.T_{\max }\right)$ are determined by differential thermal analysis (DTA) and thermogravimetric analysis (TG) in a nitrogen stream: $T_{\text {init }}=106-112{ }^{\circ} \mathrm{C}(\mathrm{DTA}), T_{\max }=147-152^{\circ} \mathrm{C}(\mathrm{DTA})$ or $144-148^{\circ} \mathrm{C}(\mathrm{TG})$. The $\mathrm{TG}$ curves obtained at a different heating rate are kinetically analyzed to evaluate an activation energy for decomposition by several methods. The decomposition rate constants, as well as overall activation energy, for the polymeric peroxide obtained from methyl sorbate are also precisely determined during the isothermal decomposition in a temperature range of $80-120^{\circ} \mathrm{C}$ by two different methods; $E_{\mathrm{a}}=86.7$ and $84.7 \mathrm{~kJ} \mathrm{~mol}^{-1}$ on the basis of the weight loss of the polymer monitored by TG analysis, and the change in the molecular weight of the polymer determined by gel permeation chromatography, respectively. It has been revealed that the thermal cleavage of the peroxy linkage and the subsequent successive $\beta$-scission produce fumaraldehyde monoester and acetaldehyde during the thermal decomposition of the alternating copolymers as the polymeric peroxides.
\end{abstract}

\section{KEY WORDS Radical Polymerization / Degradable Polymer / Thermal Degradation / Polyperoxide /}

Diene Monomer /

One of the most important organic materials is polymer degradable under mild conditions. ${ }^{1-7}$ The chemical stability of polymers is determined by the most labile linkage of atoms, of which the strength depends on the dissociation energies of chemical bonds. The repeating structure, terminal groups, and also minor irregular structures of polymers, as well as temperature, atmosphere, and other conditions, influence the rate and mechanism of decomposition. ${ }^{1}$ All vinyl polymers are made of successive $\mathrm{C}-\mathrm{C}$ bonds in their main chain, but they decompose in a different mode according to the chemical structure in their side chains. The degradation of vinyl polymers is featured by a decrease in the molecular weight and the formation of lowmolecular-weight volatile products. Some polymers are transformed into a quantitative amount of the corresponding monomer by depolymerization, as seen in the thermal decomposition of poly(methyl methacrylate) and poly $(\alpha$-methylstyrene). For several other polymers such as polyisobutene, polystyrene, and polybutadiene, depolymerization is predominant, but other types of decomposition simultaneously occur. During the decomposition of polyethylene, polypropylene, polyacrylonitrile, and poly(vinyl chloride), no depolymerization process is observed. In general, hydrocarbon-based polymers gradually decompose upon heating in an inert atmosphere, because degradation reactions are totally endothermic and the continuous supply of heat or any other equivalent energy is required to continue the decomposition. In contrast, when a polymer decomposes exothermically, it may sustain decomposition under adiabatic conditions. Occasionally decomposition rate increases during the reaction as seen in the autopyrolysis of peroxy compounds, which readily decompose via an exothermic process, namely, continue combustion even in an inert atmosphere. The synthesis and characterization of polymeric peroxides from many kinds of vinyl monomers have been carried out, ${ }^{8-24}$ since the first synthesis of a polymeric peroxide reported by Staudinger. ${ }^{25,26}$ In general, however, many synthetic procedures for polymeric peroxides are accompanied by decomposition reactions due to the less stability of the polymers as the products. For example, a peroxide polymer is formed in a high yield during the oxidative polymerization of styrene, but the simultaneous formation of benzaldehyde and formaldehyde is unavoidable and influences the polymerization kinetics and the reaction mechanism including a radical chain transfer. ${ }^{8,12,27,28}$ The accurate evaluation of the thermal properties of peroxide polymers is often hin-

${ }^{\dagger}$ To whom correspondence should be addressed (Phone/Fax: +81-6-6605-2981, E-mail: matsumoto@a-chem.eng.osaka-cu.ac.jp). 

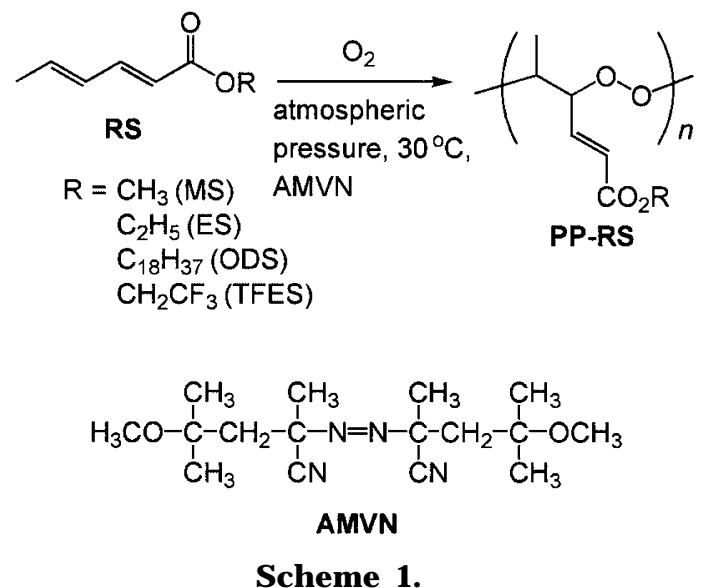

dered by contamination with decomposition products despite a large number of studies on the synthesis and characterization of peroxide polymers.

Recently, we have reported that alternating copolymers of alkyl sorbate (RS) with oxygen are conveniently prepared under atmospheric oxygen pressure conditions by photo- and thermal polymerizations in the isotropic or solid state..$^{29,30}$ In the literature, we can find only a few reports on polymeric peroxides obtained from diene monomers, ${ }^{31-33}$ in contrast to many studies on those from various vinyl monomers. Sorbic acid and its derivatives are well known as the preservatives for foods, feeds, and pharmaceuticals, ${ }^{34}$ but the structure and properties of the peroxide polymers obtained by the oxidative polymerization of sorbic derivatives have not been clarified. ${ }^{35,36}$ The resulting alternating copolymers (PP-RS) have peroxy linkages in their main chain and readily decompose to produce radicals upon heating or under photoirradiation. When the polymerization is carried out at $60^{\circ} \mathrm{C}$ or under the photoirradiation conditions, a part of the resulting PP-RS simultaneously decomposes during the polymerization. ${ }^{30}$ In this study, therefore, we carried out the radical polymerization of RS with different ester alkyl groups at $30^{\circ} \mathrm{C}$ using $2,2^{\prime}$ azobis(4-methoxy-2,4-dimethylvaleronitrile) (AMVN) as an azo initiator for low-temperature polymerization 37 (Scheme 1), in order to isolate pure polymeric peroxides without any decomposition and to accurately evaluate their thermal decomposition properties.

\section{EXPERIMENTAL}

\section{Materials}

Methyl sorbate (MS) and ethyl sorbate (ES) were purchased from Tokyo Kasei Kogyo Co., Ltd., Tokyo, and distilled under reduced pressure before use. Octadecyl sorbate (ODS) was prepared from sorbic acid and 1-octadecanol in the presence of $\mathrm{H}_{2} \mathrm{SO}_{4}$ in cyclohexane with reflux. 2,2,2-Trifluoroethyl sorbate
(TFES) was prepared from sorbic acid chloride and 2,2,2-trifluoroethanol. Spectral data for RS are shown as follows.

MS: ${ }^{1} \mathrm{HNMR}\left(400 \mathrm{MHz}, \mathrm{CDCl}_{3}\right) \delta 7.26(\mathrm{dd}$, $J=15.2$ and $9.6 \mathrm{~Hz}, \mathrm{CH}_{3} \mathrm{CH}=\mathrm{CHC} \underline{\mathrm{H}}=\mathrm{CH}, 1 \mathrm{H}$ ), 6.08-6.23 (m, $\left.\mathrm{CH}_{3} \mathrm{C} \underline{\mathrm{H}}=\mathrm{C} \underline{\mathrm{HCH}}=\mathrm{CH}, 2 \mathrm{H}\right), 5.77(\mathrm{~d}$, $\left.J=15.2 \mathrm{~Hz}, \quad \mathrm{CH}_{3} \mathrm{CH}=\mathrm{CHCH}=\mathrm{C} \underline{H}, 1 \mathrm{H}\right), 3.73(\mathrm{~s}$, $\left.\mathrm{CO}_{2} \mathrm{CH}_{3}, 3 \mathrm{H}\right), 1.85\left(\mathrm{~d}, J=5.9 \mathrm{~Hz}, \mathrm{CH}_{3} \mathrm{CH}=\mathrm{CH}\right.$, $3 \mathrm{H}) ; \quad{ }^{13} \mathrm{C} \mathrm{NMR} \quad\left(100 \mathrm{MHz}, \quad \mathrm{CDCl}_{3}\right) \quad \delta \quad 167.31$ $(\mathrm{C}=\mathrm{O}), \quad 144.84 \quad\left(\mathrm{CH}_{3} \mathrm{CH}=\mathrm{CHCH}=\mathrm{CH}\right), \quad 139.08$ $\left(\mathrm{CH}_{3} \mathrm{CH}=\underline{\mathrm{CHCH}}=\mathrm{CH}\right), 129.52\left(\mathrm{CH}_{3} \underline{\mathrm{CH}}=\mathrm{CHCH}=\mathrm{CH}\right)$, $118.30\left(\mathrm{CH}_{3} \mathrm{CH}=\mathrm{CHCH}=\underline{\mathrm{CH}}\right), 51.04\left(\mathrm{OCH}_{3}\right), 18.31$ $\left(\mathrm{CH}_{3} \mathrm{CH}=\mathrm{CH}\right)$.

ES: ${ }^{1} \mathrm{HNMR}\left(400 \mathrm{MHz}, \mathrm{CDCl}_{3}\right) \delta 7.24(\mathrm{dd}$, $J=15.2$ and $\left.10.2 \mathrm{~Hz}, \mathrm{CH}_{3} \mathrm{CH}=\mathrm{CHCH}=\mathrm{CH}, 1 \mathrm{H}\right)$, 6.09-6.22 (m, $\left.\mathrm{CH}_{3} \mathrm{C} \underline{\mathrm{H}}=\mathrm{C} \underline{\mathrm{HCH}}=\mathrm{CH}, 2 \mathrm{H}\right), 5.76(\mathrm{~d}$, $\left.J=15.2 \mathrm{~Hz}, \quad \mathrm{CH}_{3} \mathrm{CH}=\mathrm{CHCH}=\mathrm{CH}, 1 \mathrm{H}\right), 4.18(\mathrm{q}$, $\left.J=6.8 \mathrm{~Hz}, \quad \mathrm{CO}_{2} \mathrm{CH}_{2} \mathrm{CH}_{3}, 2 \mathrm{H}\right), 1.84(\mathrm{~d}, J=$ $\left.5.9 \mathrm{~Hz}, \quad \mathrm{C}_{3} \mathrm{CH}=\mathrm{CH}, \quad 3 \mathrm{H}\right), 1.28(\mathrm{t}, \quad J=6.8 \mathrm{~Hz}$, $\left.\mathrm{OCH}_{2} \mathrm{CH}_{3}, 3 \mathrm{H}\right) ;{ }^{13} \mathrm{CNMR}\left(100 \mathrm{MHz}, \mathrm{CDCl}_{3}\right) \delta$ $166.73(\mathrm{C}=\mathrm{O}), 144.45\left(\mathrm{CH}_{3} \mathrm{CH}=\mathrm{CHCH}=\mathrm{CH}\right), 138.69$ $\left(\mathrm{CH}_{3} \mathrm{CH}=\mathrm{CHCH}=\mathrm{CH}\right), 129.49\left(\mathrm{CH}_{3} \underline{\mathrm{C}} \mathrm{H}=\mathrm{CHCH}=\mathrm{CH}\right)$, $118.73\left(\overline{\mathrm{CH}}_{3} \mathrm{CH}=\mathrm{CHCH}=\underline{\mathrm{CH}}\right), \quad 59.66 \quad\left(\mathrm{OCH}_{2} \mathrm{CH}_{3}\right)$, $18.18\left(\mathrm{CH}_{3} \mathrm{CH}=\mathrm{CH}\right), 13.88\left(\mathrm{OCH}_{2} \mathrm{CH}_{3}\right)$.

ODS: ${ }^{1} \mathrm{H}$ NMR $\left(400 \mathrm{MHz}, \mathrm{CDCl}_{3}\right) \delta 7.27(\mathrm{dd}, J=$ 15.2 and $\left.9.6 \mathrm{~Hz}, \mathrm{CH}_{3} \mathrm{CH}=\mathrm{CHCH}=\mathrm{CH}, 1 \mathrm{H}\right), 6.09-$ $6.23\left(\mathrm{~m}, \mathrm{CH}_{3} \mathrm{CH}=\mathrm{CHCH}=\mathrm{CH}, \overline{2} \mathrm{H}\right), 5.78(\mathrm{~d}, J=$ $\left.15.2 \mathrm{~Hz}, \mathrm{CH}_{3} \mathrm{CH}=\mathrm{CH} \overline{\mathrm{CH}}=\mathrm{C} \underline{\mathrm{H}}, 1 \mathrm{H}\right), 4.13(\mathrm{t}, J=6.8 \mathrm{~Hz}$, $\left.\mathrm{CO}_{2} \mathrm{CH}_{2}, 2 \mathrm{H}\right), 1.86\left(\mathrm{~d}, J=5.6 \mathrm{~Hz}, \mathrm{CH}_{3} \mathrm{CH}=\mathrm{CH}, 3 \mathrm{H}\right)$, $1.62\left(\mathrm{~m}, \mathrm{CH}_{2}, 2 \mathrm{H}\right), 1.2-1.4\left(\mathrm{~m}, \mathrm{CH}_{2}, 30 \mathrm{H}\right), 0.88(\mathrm{t}, J=$ $\left.6.8 \mathrm{~Hz}, \mathrm{CH}_{2} \underline{\mathrm{C}}_{3}, 3 \mathrm{H}\right) ;{ }^{13} \mathrm{C} \mathrm{NMR}\left(100 \mathrm{MHz}, \mathrm{CDCl}_{3}\right) \delta$ $167.40(\mathrm{C}=\mathrm{O}), 144.82\left(\mathrm{CH}_{3} \mathrm{CH}=\mathrm{CHCH}=\mathrm{CH}\right), 139.15$ $\left(\mathrm{CH}_{3} \mathrm{CH}=\underline{\mathrm{CHCH}}=\mathrm{CH}\right), 129.77\left(\mathrm{CH}_{3} \underline{\mathrm{C}} \mathrm{H}=\mathrm{CHCH}=\mathrm{CH}\right)$, $119.02\left(\mathrm{CH}_{3} \mathrm{CH}=\mathrm{CHCH}=\underline{\mathrm{CH}}\right), 64.40\left(\mathrm{OCH}_{2}\right), 31.90$, $29.68,29.56,29.50,29.35,29.25,28.67,25.93$, and $22.67\left(\mathrm{CH}_{2}\right), 18.62\left(\underline{\mathrm{CH}}_{3} \mathrm{CH}=\mathrm{CH}\right), 14.10\left(\mathrm{CH}_{2} \underline{\mathrm{CH}}_{3}\right)$.

TFES: ${ }^{1} \mathrm{HNMR}\left(400 \mathrm{MHz}, \mathrm{CDCl}_{3}\right) \delta 7.35(\mathrm{dd}$, $J=15.6$ and $10.4 \mathrm{~Hz}, \mathrm{CH}_{3} \mathrm{CH}=\mathrm{CHCH}=\mathrm{CH}, 1 \mathrm{H}$ ), 6.18-6.26 (m, $\left.\mathrm{CH}_{3} \mathrm{CH}=\mathrm{CHCH}=\mathrm{CH}, 2 \overline{\mathrm{H}}\right), 5.82(\mathrm{~d}$, $\left.J=15.6 \mathrm{~Hz}, \quad \mathrm{CH}_{3} \mathrm{CH}=\mathrm{CHCH}=\mathrm{CH}, 1 \mathrm{H}\right), 4.53 \quad(\mathrm{q}$, $\left.J=8.8 \mathrm{~Hz}, \mathrm{CO}_{2} \mathrm{CH}_{2} \mathrm{CF}_{3}, 2 \mathrm{H}\right), 1.90(\mathrm{~d}, J=5 \mathrm{~Hz}$, $\left.\mathrm{CH}_{3} \mathrm{CH}=\mathrm{CH}, 3 \mathrm{H}\right) ;{ }^{13} \mathrm{C}$ NMR $\left(100 \mathrm{MHz}, \mathrm{CDCl}_{3}\right) \delta$ $165.31(\mathrm{C}=\mathrm{O}), 147.33\left(\mathrm{CH}_{3} \mathrm{CH}=\mathrm{CHCH}=\mathrm{CH}\right), 141.19$ $\left(\mathrm{CH}_{3} \mathrm{CH}=\underline{\mathrm{CHCH}}=\mathrm{CH}\right), 129.49\left(\mathrm{CH}_{3} \underline{\underline{\mathrm{C}}} \mathrm{H}=\mathrm{CHCH}=\mathrm{CH}\right)$, $123.05 \quad\left(\overline{\mathrm{OCH}}_{2} \underline{\mathrm{CF}}_{3}\right), \quad 60.00 \quad\left(\mathrm{O}^{-} \mathrm{CH}_{2} \mathrm{CF}_{3}\right), \quad 18.52$ $\left(\mathrm{CH}_{3} \mathrm{CH}=\mathrm{CH}\right)$.

Diethyl muconate was prepared by the method previously reported. ${ }^{38}(2 E, 4 E)$-2,4-Hexadiene (HD), methyl acrylate, methyl methacrylate, methyl crotonate, vinyl acetate, styrene, and $\alpha$-methylstyrene were commercially available and distilled before use. 2, 2 -Azobis(4methoxy-2,4-dimethylvaleronitrile) (AMVN) and 2,2'azobis(isobutyronitrile) (AIBN) were purchased from 
Wako Pure Chemical Industries, Ltd., Osaka, and recrystallized from methanol. Di-tert-butyl peroxide (Tokyo Kasei Kogyo Co., Ltd., Tokyo) was used without any further purification. The solvents were purified by conventional methods.

\section{Polymerization}

After the required amounts of a monomer, an initiator $($ monomer/initiator $=50 / 1$ in weight), and 1,2 dichloroethane $($ monomer/solvent $=1 / 1$ in weight) were charged in an unsealed Pyrex tube, polymerization was carried out with the bubbling of air or $\mathrm{O}_{2}$. A small amount $(0.2-2 \mathrm{~g}$, typically $1 \mathrm{~g})$ of monomers were used for each run of polymerization. After the polymerization, the contents of the tube were poured into a large amount of precipitant to isolate the resulting polymer: $n$-hexane was used as the precipitant for the polymerizations of MS, ES, TFES, diethyl muconate, methyl crotonate, methyl acrylate, and vinyl acetate; ethanol for ODS; distilled water and methanol mixture (1/1 in volume) for HD, methyl methacrylate, styrene and $\alpha$-methylstyrene. The polymer yield is expressed as an apparent value on the basis of the amount of the vinyl and diene monomers in the feed. The polymer was dried in vacuo at room temperature, and purified by reprecipitation. During all the procedures of isolation and purification, the polymer should be treated without heating and contact with any reducing agents and metal to avoid explosive decomposition, although it can be handled according to the conventional procedures at room temperature.

PP-MS: ${ }^{1} \mathrm{H} \mathrm{NMR}\left(400 \mathrm{MHz}, \mathrm{CDCl}_{3}\right) \quad \delta \quad 6.8-7.0$ $\left(\mathrm{CH}=\mathrm{CHCO}_{2}, 1 \mathrm{H}\right), 6.0-6.2\left(\mathrm{C} \underline{\mathrm{H}}=\mathrm{CHCO}_{2}, 1 \mathrm{H}\right), 4.2-$ $5.1(\mathrm{CH}, 2 \mathrm{H}), 3.7-3.9\left(\mathrm{OCH}_{3}, 3 \mathrm{H}\right), 1.0-1.4\left(\mathrm{CH}_{3}\right.$, $3 \mathrm{H})$.

PP-ES: ${ }^{1} \mathrm{HNMR}\left(400 \mathrm{MHz}, \mathrm{CDCl}_{3}\right) \quad \delta \quad 6.8-7.0$ $\left(\mathrm{CH}=\mathrm{C}_{\underline{H}} \mathrm{O}_{2}, 1 \mathrm{H}\right), 6.0-6.2\left(\mathrm{C} \underline{\mathrm{H}}=\mathrm{CHCO}_{2}, 1 \mathrm{H}\right), 4.0$ $5.1\left(\mathrm{CH}\right.$ and $\left.\mathrm{OCH}_{2}, 4 \mathrm{H}\right), 0.8-1.4\left(\mathrm{CH}_{3}, 6 \mathrm{H}\right)$.

PP-ODS: ${ }^{1} \mathrm{H}$ NMR $\left(400 \mathrm{MHz}, \mathrm{CDCl}_{3}\right) \delta 6.8-7.0$ $\left(\mathrm{CH}=\mathrm{CHCO}_{2}, 1 \mathrm{H}\right), 6.0-6.2\left(\mathrm{C} \underline{\mathrm{H}}=\mathrm{CHCO}_{2}, 1 \mathrm{H}\right), 3.8-$ $5.1\left(\mathrm{CH}\right.$ and $\left.\mathrm{OCH}_{2}, 4 \mathrm{H}\right), 0.8-1.7\left(\mathrm{CH}_{2}\right.$ and $\left.\mathrm{CH}_{3}, 38 \mathrm{H}\right)$. PP-TFES: ${ }^{1} \mathrm{H}$ NMR $\left(400 \mathrm{MHz}, \mathrm{CDCl}_{3}\right) \delta 6.9-7.1$ $\left(\mathrm{CH}=\mathrm{CHCO}_{2}, 1 \mathrm{H}\right), 6.1-6.3\left(\mathrm{C} \underline{\mathrm{H}}=\mathrm{CHCO}_{2}, 1 \mathrm{H}\right), 4.2-$ $5.1\left(\mathrm{CH}\right.$ and $\left.\mathrm{OCH}_{2}, 4 \mathrm{H}\right), 1.0-1.4\left(\mathrm{CH}_{3}, 3 \mathrm{H}\right)$.

PP-HD: ${ }^{1} \mathrm{H}$ NMR $\left(400 \mathrm{MHz}, \mathrm{CDCl}_{3}\right) \delta$ 5.3-5.9 $(\mathrm{CH}=\mathrm{CH}, 2 \mathrm{H}), 4.2-4.7(\mathrm{CH}, 2 \mathrm{H}), 1.0-1.8\left(\mathrm{CH}_{3}, 6 \mathrm{H}\right)$; ${ }^{13} \mathrm{C}$ NMR $\left(100 \mathrm{MHz}, \mathrm{CDCl}_{3}\right) \quad \delta 125-133(\mathrm{CH}=\mathrm{CH})$, 78-86 (CH), $13-18\left(\mathrm{CH}_{3}\right)$.

Homopolymerization of MS was carried out in toluene (monomer/solvent $=1 / 3$ in weight) at $120^{\circ} \mathrm{C}$ for $24 \mathrm{~h}$ in the presence of di-tert-butyl peroxide (monomer/initiator $=50 / 1$ in weight $)$ in a sealed Pyrex tube. ${ }^{39}$ After the polymerization, the contents of the tube were poured into a large amount of $n$-hexane to isolate the resulting polymer, which was dried in vacuo at room temperature.

Homopoly(MS): ${ }^{1} \mathrm{H}$ NMR $\left(400 \mathrm{MHz}, \mathrm{CDCl}_{3}\right) \delta 5.1-$ $5.6(\mathrm{CH}=\mathrm{CH}, 2 \mathrm{H}), 3.5-3.9\left(\mathrm{OCH}_{3}, 3 \mathrm{H}\right), 1.6-3.5(\mathrm{CH}$, $2 \mathrm{H}), 0.7-1.1\left(\mathrm{CH}_{3}, 3 \mathrm{H}\right)$.

\section{Measurements}

Number- and weight-average molecular weights $\left(M_{\mathrm{n}}\right.$ and $M_{\mathrm{w}}$ ) were determined by gel permeation chromatography (GPC) at $38^{\circ} \mathrm{C}$ in tetrahydrofuran (THF) as an eluent using a Tosoh GPC-8000 series system and calibrated with standard polystyrenes. NMR spectra were recorded on a JEOL JMN A-400 spectrometer. Differential scanning calorimetry (DSC) was carried out with SEIKO DSC 6200 in a nitrogen stream at a heating or cooling rate of $5^{\circ} \mathrm{Cmin}^{-1}$. The sample weight was approximately $10 \mathrm{mg}$. Thermogravimetric and differential thermal analyses (TG and DTA) were carried out with a SEIKO TG/DTA 6200 in a nitrogen stream at a heating rate of $10^{\circ} \mathrm{C} \mathrm{min}^{-1}$. For kinetic analysis, the heating rate was changed in the range of $5-80^{\circ} \mathrm{C} \mathrm{min}^{-1}$. The sample weight was approximately $1 \mathrm{mg}$. TG was also carried out under isothermal conditions. The heat of decomposition $(\Delta H)$ was approximately estimated from a peak area $(S)$ in a DTA curve (unit is $\mathrm{V} \mathrm{s} \mathrm{g}^{-1}$ ) combined with the device constant $\left(1.77 \times 10^{12} \mathrm{~V} \mathrm{~s} \mathrm{~kJ}^{-1}\right)$, which was determined using $\mathrm{AgNO}_{3}$ and $\mathrm{KNO}_{3}$ as the reference compounds.

\section{RESULTS AND DISCUSSION}

\section{Synthesis of Alternating Copolymers}

The results of the copolymerization of MS with oxygen under various conditions are summarized in Table I. The copolymer was produced during the thermal and photopolymerization in the presence or absence of AIBN under atmospheric pressure of oxygen or air. Sunlight was also available as the light source. The $M_{\mathrm{n}}$ and $M_{\mathrm{w}} / M_{\mathrm{n}}$ values of the obtained copolymers were $(2.1-2.6) \times 10^{3}$ and $1.5-2.2$, respectively. In the ${ }^{1} \mathrm{H}$ NMR spectrum of the obtained polymer, the characteristic peaks of vinylene protons as the pendant in the side chains were observed at 6.1 and $6.9 \mathrm{ppm}$ as well as the splitting of peaks at $4-5 \mathrm{ppm}$ due to the methine protons in the main chain. ${ }^{29,30}$ The NMR spectroscopy supports the formation of an alternating copolymer of MS with oxygen with a 5,4 structure as the repeating unit, as shown in Scheme 1. During the thermal and photopolymerizations under these conditions, the polymer yield increased with the polymerization time, while the $M_{\mathrm{n}}$ values decreased as a function of the time. These results are due to the simultaneous photo- 
Table I. Radical copolymerization of MS with oxygen under various conditions ${ }^{\mathrm{a}}$

\begin{tabular}{lcllcrccc}
\hline Run & $\begin{array}{c}\text { Temp. } \\
\left({ }^{\circ} \mathrm{C}\right)\end{array}$ & Light Source & Initiator & Atmosphere & $\begin{array}{c}\text { Time } \\
(\mathrm{h})\end{array}$ & $\begin{array}{c}\text { Yield } \\
(\%)\end{array}$ & $M_{\mathrm{n}} \times 10^{-3}$ & $M_{\mathrm{w}} / M_{\mathrm{n}}$ \\
\hline 1 & 65 & In the dark & AIBN $^{\mathrm{b}}$ & Air & 1 & 14.3 & 2.5 & 1.6 \\
2 & 65 & In the dark & AIBN $^{\mathrm{b}}$ & Air & 10 & 25.3 & 2.1 & 1.5 \\
$3^{\mathrm{c}}$ & 60 & $\mathrm{Hg}$ lamp & None & Air & 4 & 40.0 & 2.6 & 1.9 \\
$4^{\mathrm{c}}$ & 60 & Hg lamp & None & Air & 6 & 56.4 & 2.5 & 2.2 \\
$5^{\mathrm{c}}$ & 60 & Hg lamp & None & Air & 10 & 64.0 & 2.1 & 1.7 \\
$6^{\mathrm{c}}$ & r.t. & Sunlight & None & Air & 6 & 29.3 & 2.2 & 1.6 \\
7 & 30 & In the dark & AMVN $^{\mathrm{b}}$ & Air & 6 & 15.4 & 2.3 & 1.8 \\
8 & 30 & In the dark & AMVN $^{\mathrm{b}}$ & $\mathrm{O}_{2}$ & 1 & 11.1 & 3.2 & 1.7 \\
9 & 30 & In the dark & AMVN $^{\mathrm{b}}$ & $\mathrm{O}_{2}$ & 6 & 43.5 & 3.3 & 1.7 \\
10 & 30 & In the dark & AMVN $^{\mathrm{b}}$ & $\mathrm{O}_{2}$ & 10 & 43.7 & - & - \\
11 & 30 & In the dark & AMVN $^{\mathrm{b}, \mathrm{d}}$ & $\mathrm{O}_{2}$ & 8 & 60.7 & - & - \\
12 & 30 & In the dark & AMVN $^{\mathrm{b}, \mathrm{d}}$ & $\mathrm{O}_{2}$ & 10 & 76.2 & - & - \\
\hline
\end{tabular}

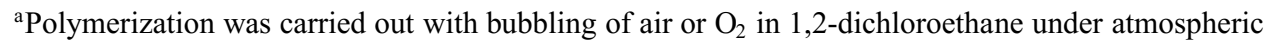
pressure. MS/1,2-dichloroethane $=1 / 1$ in weight. $M_{\mathrm{n}}$ and $M_{\mathrm{w}} / M_{\mathrm{n}}$ were determined by GPC calibrated with standard polystyrenes. ${ }^{\mathrm{b}} \mathrm{MS} /$ initiator $=50 / 1$ in weight. ${ }^{\mathrm{c}}$ Polymerized in bulk (ref 30). ${ }^{\mathrm{d}} \mathrm{MS} 2 \mathrm{~g}$, AMVN $40 \mathrm{mg}$, 1,2-dichloroethane $2 \mathrm{~g} .10 \mathrm{mg}$ of AMVN was added stepwise in 2-h interval after the 4-h polymerization (see also Figure 1).

and thermal decomposition during the polymerization of MS under the photoirradiation and high temperature conditions.

In order to prevent the decomposition of the produced PP-MS during the polymerization, MS was polymerized at $30^{\circ} \mathrm{C}$ in the dark in the presence of AMVN, which decomposes at a moderate rate even at such a low temperature. The isolated polymers have constant $M_{\mathrm{n}}$ and $M_{\mathrm{w}} / M_{\mathrm{n}}$ values with a unimodal molecular weight distribution, irrespective of the polymerization time. During the polymerization of MS initiated with AMVN, the polymer yield increased linearly against time in the first stage of the polymerization, but it kept constant after the 6-h polymerization, due to the too fast decomposition of AMVN even at $30^{\circ} \mathrm{C}$ (Figure 1). The rate constant for the decomposition of commercial AMVN as a mixture of racemic and meso isomers is $1.9 \times 10^{-5} \mathrm{~s}^{-1}$ at $30^{\circ} \mathrm{C},{ }^{40}$ providing a half-life time of about $10 \mathrm{~h}$ at $30^{\circ} \mathrm{C}$. It has recently been pointed out that the racemic isomer decomposes more rapidly than the meso isomer; a half-life time is reported to be approximately $1 \mathrm{~h}$ at $30^{\circ} \mathrm{C}$ for the racemic isomer. ${ }^{37}$ The deadend type polymerization is possibly due to the fast decomposition of AMVN. In fact, the stepwise addition of AMVN was effective at getting a higher polymer yield. When each portion of a small amount of AMVN was stepwise added in a 2-h interval after the 4-h polymerization under the conditions identical to those for the dead-end polymerization described above, the polymer yield increased linearly to reach $c a$. $80 \%$ yield for the 10-h polymerization.

Similar copolymerization was carried out using several RS with a different ester alkyl group to synthesize various types of alternating copolymers. The results are

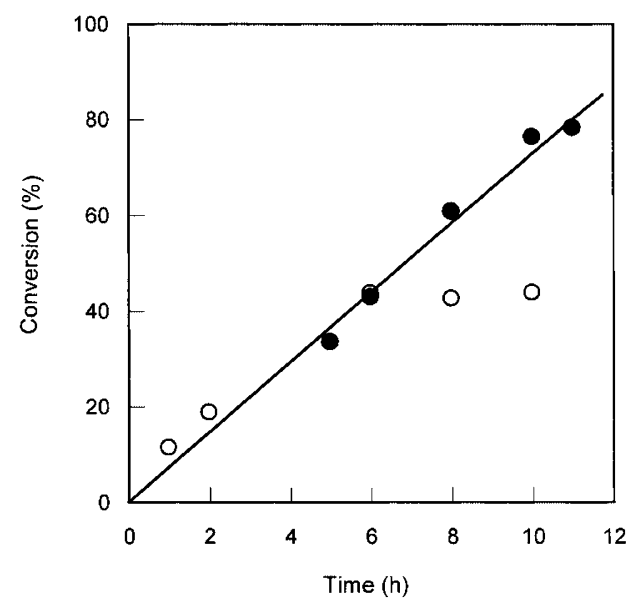

Figure 1. Polymerization of $\mathrm{MS}$ with $\mathrm{O}_{2}$ in the presence of $\mathrm{AMVN}$ at $30^{\circ} \mathrm{C}$. MS/1,2-dichloroethane $=1 / 1$ in weight, $\mathrm{MS} / \mathrm{AMVN}=50 / 1$ in weight. MS $2 \mathrm{~g}$, AMVN $40 \mathrm{mg}, 1,2-$ dichloroethane $2 \mathrm{~g}$. $(\bigcirc)$ Without further addition of AMVN, (O) $10 \mathrm{mg}$ of AMVN was added stepwise in 2-h interval after the 4-h polymerization.

summarized in Table II. During the polymerization in the presence of AMVN at $30^{\circ} \mathrm{C}$ with the bubbling of air or oxygen, the RS monomers provided the corresponding polymers, PP-RS. The yield, $M_{\mathrm{n}}$, and $M_{\mathrm{w}} / M_{\mathrm{n}}$ values of the obtained copolymers were $12.9-43.5 \%$, $(2.3-8.6) \times 10^{3}$, and $1.4-1.8$, respectively. The order in the $M_{\mathrm{n}}$ values is PP-MS < PP-ES < PP-TFES < PPODS, but the degree of polymerization $\left(P_{\mathrm{n}}\right)$ is similar for all the polymers; $P_{\mathrm{n}}=21-24$. When the copolymerization was carried out with the bubbling of oxygen, the yield and molecular weight were larger than those for the copolymer obtained with the bubbling of air. These data suggest that the yield and molecular weight of the polymer depend on partial oxygen pres- 

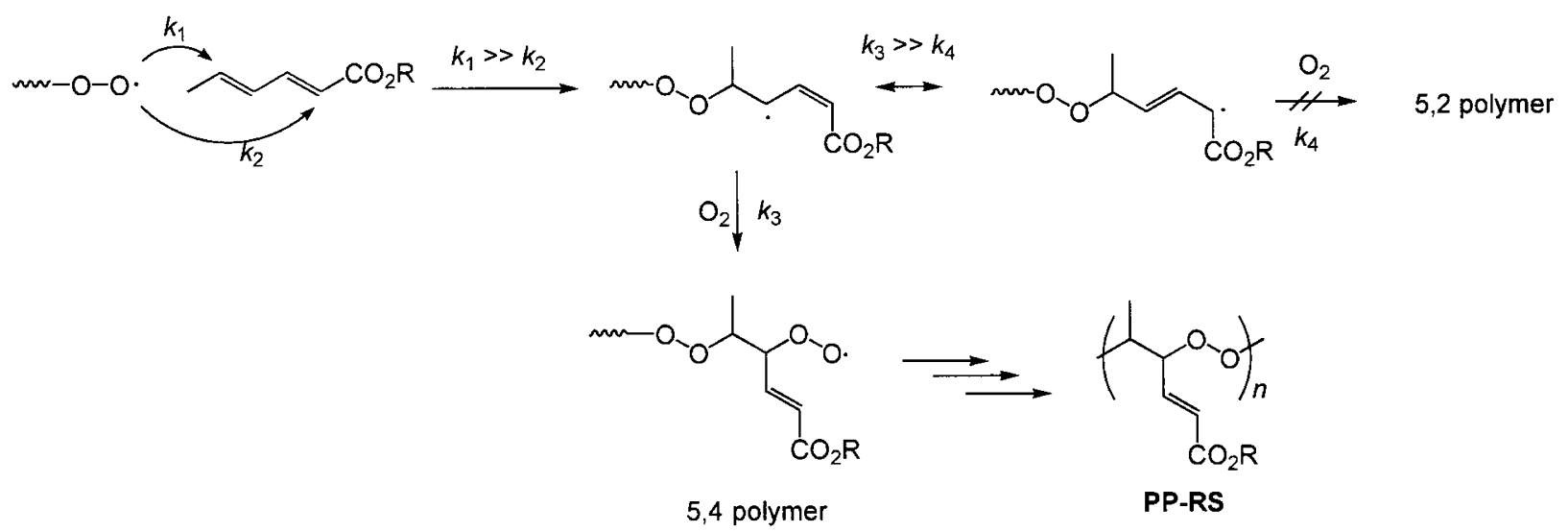

Scheme 2.

Table II. Polymerization of several diene and vinyl monomers in the presence of oxygen in 1,2-dichloroethane ${ }^{a}$

\begin{tabular}{lcccc}
\hline Monomer & Atmosphere & Yield $(\%)$ & $M_{\mathrm{n}} \times 10^{-3}$ & $M_{\mathrm{w}} / M_{\mathrm{n}}$ \\
\hline MS & Air & 15.4 & 2.3 & 1.8 \\
& $\mathrm{O}_{2}$ & 43.5 & 3.3 & 1.7 \\
& & $(49.3)^{\mathrm{b}}$ & $(3.3)^{\mathrm{b}}$ & $(1.7)^{\mathrm{b}}$ \\
ES & $\mathrm{Air}$ & 13.7 & 3.3 & 1.7 \\
& $\mathrm{O}_{2}$ & 39.1 & 4.0 & 1.8 \\
ODS & $\mathrm{Air}$ & 12.9 & 6.9 & 1.4 \\
& $\mathrm{O}_{2}$ & 30.4 & 8.6 & 1.4 \\
TFES & $\mathrm{O}_{2}$ & 43.1 & 5.4 & 1.5 \\
$\mathrm{HD}$ & $\mathrm{O}_{2}$ & 14.5 & 5.0 & 1.5 \\
Diethyl muconate & $\mathrm{O}_{2}$ & $\sim 0$ & - & - \\
Methyl acrylate & $\mathrm{O}_{2}$ & $\sim 0$ & - & - \\
Methyl methacrylate & $\mathrm{O}_{2}$ & $\sim 0$ & - & - \\
Methyl crotonate & $\mathrm{O}_{2}$ & $\sim 0$ & - & - \\
Vinyl acetate & $\mathrm{O}_{2}$ & $\sim 0$ & - & - \\
Styrene & $\mathrm{O}_{2}$ & 12.6 & $<1.0$ & - \\
$\alpha-$ Methylstyrene & $\mathrm{O}_{2}$ & 2.5 & $<1.0$ & - \\
\hline
\end{tabular}

${ }^{\text {a}}$ Polymerization was carried out with bubbling of air or $\mathrm{O}_{2}$ in 1,2-dichloroethane under atmospheric pressure in the presence of $\mathrm{AMVN}$ at $30^{\circ} \mathrm{C}$ in the dark for $6 \mathrm{~h}$. Monomer/AMVN $=$ $50 / 1$ in weight. Monomer/1,2-dichloroethane $=1 / 1$ in weight. $M_{\mathrm{n}}$ and $M_{\mathrm{w}} / M_{\mathrm{n}}$ were determined by GPC calibrated with standard polystyrenes. ${ }^{b}$ Under UV irradiation in the absence of an initiator at $60^{\circ} \mathrm{C}$. Monomer $/ 1,2$-dichloroethane $=1 / 5$ in weight.

sure in the present polymerization system, although the copolymers always have an alternating structure under these conditions.

In contrast to the facile production of PP-RS, vinyl monomers such as methyl acrylate, methyl methacrylate, methyl crotonate, and vinyl acetate did not provide a polymer under the identical conditions. Styrene and $\alpha$-methylstyrene provided oligomers $\left(M_{\mathrm{n}}<10^{3}\right)$ in a low yield under atmospheric pressure conditions in this work. NMR analysis revealed that the oligomers obtained under the present conditions contain not only the alternating repeating structure but also the homopolymerization sequence, whereas it has been reported that styrene derivatives provide an alternating copolymer in a high yield under high-pressure conditions of oxygen. ${ }^{12}$

We propose a mechanism for an efficient alternating propagation to provide PP-RS with a 5,4 repeating structure (Scheme 2). A propagating peroxy radical tends to add to the $\mathrm{C} 5$ carbon, but not the $\mathrm{C} 2$ carbon of the RS monomer, due to the greater electrophilicity of the peroxy radical $\left(k_{1} \gg k_{2}\right)^{41-43}$ and electron density diminished by the existence of an electron-withdrawing carbonyl group. Furthermore, an attack on the C5 carbon results in the favorable structure of an allyl radical, the unpaired electron of which can also resonate to the carbonyl group. The addition of a peroxy radical to a diene monomer is considered to be a rate-determining step. ${ }^{43}$ The radical on the $\mathrm{C} 4$ carbon of RS preferably reacts with oxygen, because the homo-propagation slowly proceeds between the stable RS radical with a conjugated structure and the sterically hindered RS monomer as the internal diene compound. ${ }^{38,39}$ The 5,2 propagation is suppressed because of less affinity for a reaction with oxygen (i.e., $k_{3} \gg k_{4}$ in Scheme 2). As a result, an alternating propagation proceeds with a high selectivity, leading to the formation of an exclusive 5,4 polymer.

To confirm this reaction mechanism for alternating propagation, the polymerization of related diene monomers with a symmetric structure was investigated. When the copolymerization of HD with oxygen was carried out under the conditions identical to those for the RS polymerization, a copolymer was produced; yield $14.5 \%, M_{\mathrm{n}}=5.0 \times 10^{3}\left(P_{\mathrm{n}}=44\right)$, and $M_{\mathrm{w}} / M_{\mathrm{n}}=$ 1.5 , as shown in Table II. On the other hand, diethyl muconate provided no polymer under similar conditions. The results for the reactions with these two monomers are interpreted by the mechanism shown in Schemes 3 and 4, respectively. During the polymerization of HD, the propagating peroxy radical attacks the $\mathrm{C} 2$ carbon of HD. The reaction rate is probably greater 


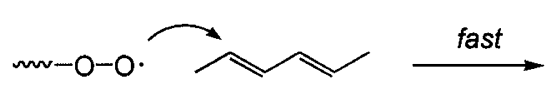

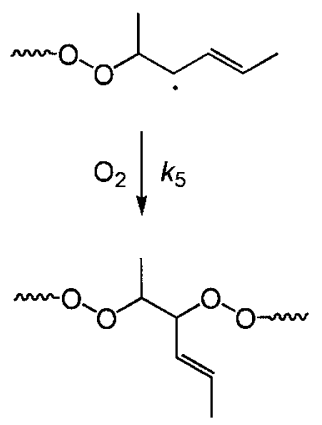

2,3 polymer $(21 \%)$

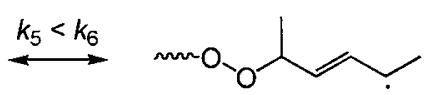

$\mathrm{O}_{2} \downarrow k_{6}$<smiles>COOC(C)/C=C/C(C)OOC</smiles>

2,5 polymer $(79 \%)$

Scheme 3.

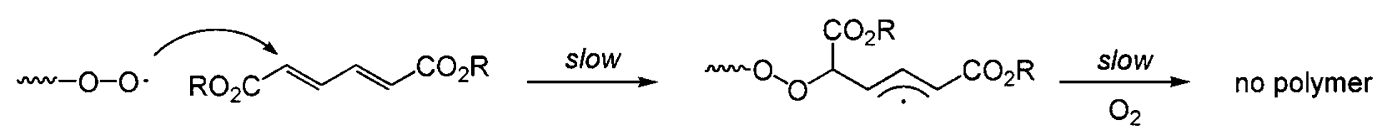

Scheme 4
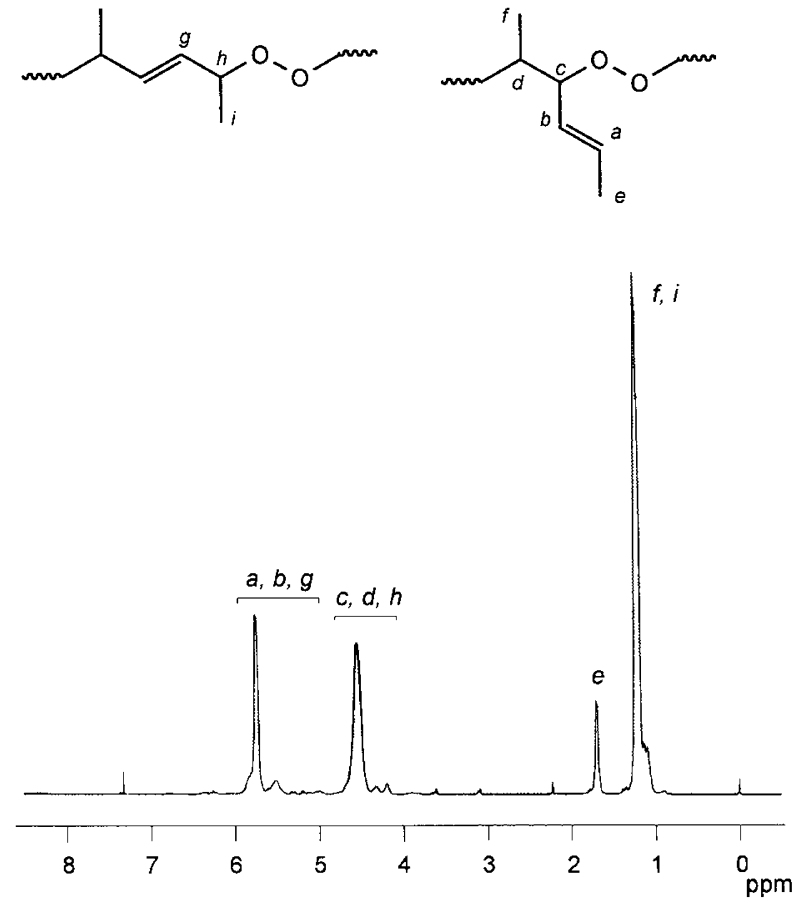

Figure 2. ${ }^{1} \mathrm{H}$ NMR spectrum of PP-HD.

than that for the attack to RS due to the difference in the electron density and the structural symmetry of the monomer. The HD propagating radical can react with oxygen in two kinds of propagating fashions, resulting in 2,3 and 2,5 units as the repeating structure. Actually, NMR spectroscopy suggests the existence of both the 2,3 and 2,5 structures (21 and 79\%, respectively) in PP-HD (Figure 2). During the reaction of diethyl muconate, the diene dicarboxylate monomer reacts with a peroxy radical at a very slow rate due to the deficient electron density on the double bond. The muconate propagating radical can attack oxygen, but its rate is also very low due to the diminished energy level of the highest occupied molecular orbital (HOMO) for the muconate, which has two electron withdrawing substituents. ${ }^{43}$ As a result, no polymer is formed. The homopolymerization also proceeds only at a considerably low rate under the conditions in this work, that is, at a low temperature and a low monomer concentration. ${ }^{38}$ In the case of the muconate polymerization, a molecular oxygen behaviors as a terminator rather than comonomer.

The $T_{\mathrm{g}}$ values of PP-MS, PP-ES, PP-TFS, and PPHD were $-10.7,-13.0,-8.5$, and $-36.6{ }^{\circ} \mathrm{C}$, respectively (see Table III), being consistent with the fact that they are isolated as tacky polymers at room temperature. PP-ODS is a solid polymer at room temperature, and shows an endothermic peak due to the melting of the long alkyl side chains in a DSC trace during the heating process $\left(T_{\mathrm{m}}=52.3^{\circ} \mathrm{C}\right)$. An enthalpy change associated with the melting of the side chain was $32.1 \mathrm{~kJ} \mathrm{unit}^{-1}$, being similar to literature values for comb-like polymers with an octadecyl side chain. ${ }^{44,45}$

\section{Thermal Decomposition of PP-RS}

Figure 3 shows the results of TG/DTA curves of PP-MS and the homopolymer of MS [homopoly(MS)] in a nitrogen stream at a heating rate of $10^{\circ} \mathrm{C} \mathrm{min}^{-1}$. Homopoly(MS) was prepared by radical polymerization in toluene at $120^{\circ} \mathrm{C}$ in the absence of oxygen. The $M_{\mathrm{n}}$ and $M_{\mathrm{w}} / M_{\mathrm{n}}$ were $5.0 \times 10^{3}$ and 1.2 , respectively. It is an atactic polymer consisting of predominantly a 2,5 trans structure as the repeating unit. The thermal analysis shows that the exothermic decomposition of PP-MS starts from a low temperature around $100^{\circ} \mathrm{C}$, while homopoly(MS) endothermically decomposes over $300^{\circ} \mathrm{C}$. Thus, the degradation behavior of the alternating copolymers with oxygen was different from that of the homopolymer having successive $\mathrm{C}-\mathrm{C}$ bonds in the main chain. The heat of the decomposition 
Table III. Results of TG/DTA and DSC analysis for PP-RS ${ }^{\mathrm{a}}$

\begin{tabular}{lrccccc}
\hline Copolymers & $\begin{array}{c}T_{\text {init }}(\mathrm{DTA}) \\
\left({ }^{\circ} \mathrm{C}\right)\end{array}$ & $\begin{array}{c}T_{\max }(\mathrm{DTA}) \\
\left({ }^{\circ} \mathrm{C}\right)\end{array}$ & $\begin{array}{c}T_{\max }(\mathrm{TG}) \\
\left({ }^{\circ} \mathrm{C}\right)\end{array}$ & $\begin{array}{c}S(\mathrm{DTA}) \\
\left(\mathrm{V} \mathrm{s} \mathrm{g}^{-1}\right)\end{array}$ & $\begin{array}{c}S^{\prime}(\mathrm{DTA}) \times 10^{-2} \\
\left(\mathrm{~V} \mathrm{~s} \mathrm{unit}^{-1}\right)\end{array}$ & $\begin{array}{c}T_{\mathrm{g}} \\
\left({ }^{\circ} \mathrm{C}\right)\end{array}$ \\
\hline PP-MS & 107.9 & 147.5 & 148.2 & 2.10 & 3.31 & -10.7 \\
PP-MS-60 & 93.6 & 153.3 & 154.2 & 1.11 & 1.75 & -9.4 \\
PP-ES & 107.4 & 147.0 & 145.3 & 1.93 & 3.32 & -13.0 \\
PP-ODS & 112.4 & 152.2 & 144.5 & 0.89 & 3.52 & $(52.3)^{\mathrm{c}}$ \\
PP-TFES & 106.5 & 147.5 & 144.6 & 1.51 & 3.41 & -8.5 \\
PP-HD & 95.1 & 151.6 & 154.2 & 4.07 & 4.64 & -36.6 \\
\hline
\end{tabular}

${ }^{\text {a}}$ The copolymers were prepared by the polymerization with bubbling of $\mathrm{O}_{2}$ in the presence of AMVN at $30^{\circ} \mathrm{C}$. The $T_{\text {init }}$ and $T_{\max }$ values were determined by TG/DTA at a heating rate of $10^{\circ} \mathrm{C} \mathrm{min}{ }^{-1}$ in a nitrogen stream. $S$ (DTA) and $S^{\prime}(\mathrm{DTA})$ are the peak areas of DTA curves per the weight and repeating unit of the polymers. The $T_{\mathrm{g}}$ value was determined by DSC at a heating rate of $10^{\circ} \mathrm{C} \mathrm{min}^{-1}$ in a nitrogen stream. ${ }^{\mathrm{b}}$ Prepared by the polymerization in the absence of an initiator under UV irradiation at $60{ }^{\circ} \mathrm{C}$. ${ }^{\mathrm{c}}$ Melting point of the long alkyl side chains of the polymer.

(a)

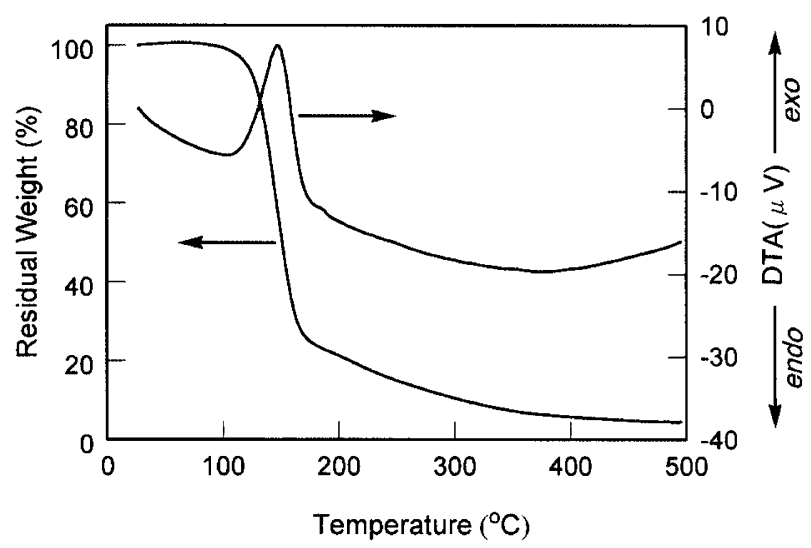

(b)

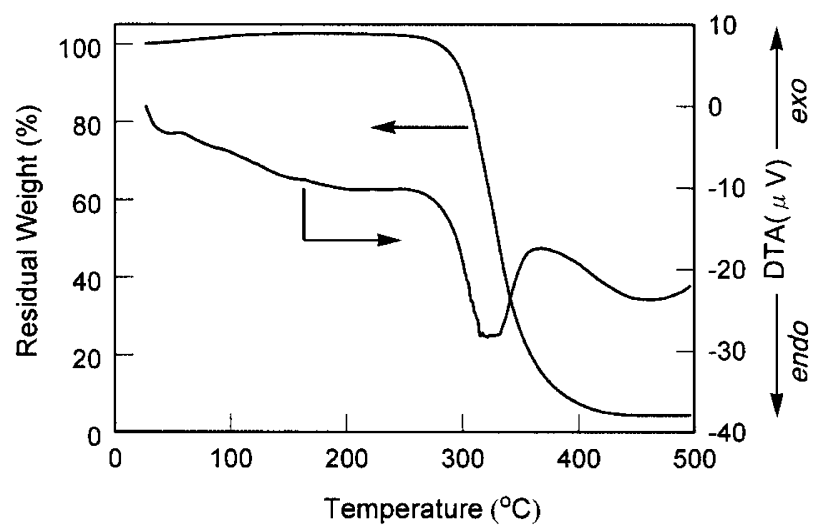

Figure 3. TG and DTA curves of (a) PP-MS and (b) homopoly(MS) in a nitrogen stream at a heating rate of $10^{\circ} \mathrm{C} \mathrm{min}^{-1}$. Sample weight is $c a .1 \mathrm{mg}$.

was so large that the heating rate $\left(10^{\circ} \mathrm{C} \mathrm{min}^{-1}\right)$ could not be controlled when a large amount of PP-MS was provided for the TG/DTA measurement. For example, when $c a$. $10 \mathrm{mg}$ of PP-MS was used for the TG/DTA experiment, the temperature increased autocatalytically by $70-80^{\circ} \mathrm{C}$ higher than the desired temperature of a heating process. Therefore, we carried out the analysis using a small amount of polymer ( $c a .1 \mathrm{mg}$ ) to prevent explosive decomposition. A similar feature has also been pointed out for the other kinds of polyperoxides obtained from various vinyl monomers by Kishore et al. ${ }^{46}$

The initial decomposition temperature ( $\left.T_{\text {init }}\right)$ and the maximum decomposition temperature $\left(T_{\max }\right)$ were determined from the TG/DTA data (Table III). For all the polymers obtained from RS, the $T_{\text {init }}$ and $T_{\max }$ were almost the same: $T_{\text {init }}=106.5-112.4^{\circ} \mathrm{C}$ and $T_{\max }=$ $144.5-148.2^{\circ} \mathrm{C}$. We also estimated the heat of the decomposition per repeating unit $\left(\Delta H_{\text {unit }}\right)$ from the peak intensity of a DTA curve. The peak areas were determined per the weight and the repeating unit of the polymers ( $S$ and $S$ ', respectively), and they are summarized in Table III. The $S$ ' values agreed well with one another for all the PP-RS (3.3-3.5 V s unit $\left.{ }^{-1}\right)$. The values approximately correspond to $-(187-196) \mathrm{kJ} \mathrm{unit}^{-1}$ as the $\Delta H_{\text {unit }}$ value. We have concluded that PP-RS decomposes via an exothermic process in a similar thermal decomposition mechanism, irrespective of the structure of the ester alkyl group. The decomposition behavior of PP-MS prepared by the photopolymerization with a high-pressure mercury lamp at $60^{\circ} \mathrm{C}$ (PP-MS-60 in Table III) was different from that of PP-MS prepared with AMVN at $30^{\circ} \mathrm{C}$. In contrast to the rapid weight loss in a TG curve for PP-MS with a well-defined chain structure obtained by the low temperature polymerization using AMVN, the weight of PP-MS-60 gradually decreased and a weight residue was much greater at $200^{\circ} \mathrm{C}$. The latter polymer has also a smaller $S$ ' (i.e., $\left.\Delta H_{\text {unit }}\right)$ value. These results are due to the cleavage of some peroxy linkages in the polymers, followed by hydrogen abstraction and other reactions during the photopolymerization at $60^{\circ} \mathrm{C}$, resulting in an irregular and less-degradable structure. PP-HD also decomposes exothermically $\left(T_{\text {init }}=95.1{ }^{\circ} \mathrm{C}\right.$ and $\left.T_{\max }=154.2^{\circ} \mathrm{C}\right)$.

Scheme 5 shows the thermal decomposition mecha- 
Table IV. Kinetic analysis of TG data of PP-RS under non-isothermal conditions according to three different methods ${ }^{\mathrm{a}}$

\begin{tabular}{llll}
\hline Polymer & Method & Heating rate, $\beta\left({ }^{\circ} \mathrm{C} \mathrm{min}^{-1}\right)$ & $E_{\mathrm{a}}\left(\mathrm{kJ} \mathrm{mol}^{-1}\right)$ \\
\hline PP-MS & Ozawa & $5,10,20,40,80$ & $93.7(\alpha=0.1)^{\mathrm{b}}$ \\
& & & $119(\alpha=0.3)$ \\
& & & $127(\alpha=0.5)$ \\
& & $5,10,20,40,80$ & $134(\alpha=0.7)$ \\
PP-MS & Kissinger & 132 \\
PP-MS & Coates and Redfern & 10 & $117\left(100-160^{\circ} \mathrm{C}\right)$ \\
PP-ES & Coates and Redfern & 10 & $125\left(115-165^{\circ} \mathrm{C}\right)$ \\
PP-ODS & Coates and Redfern & 10 & $143\left(140-160^{\circ} \mathrm{C}\right)$ \\
PP-TEFS & Coates and Redfern & 10 & $106\left(100-160^{\circ} \mathrm{C}\right)$ \\
PP-HD & Coates and Redfern & 10 & $131\left(100-160^{\circ} \mathrm{C}\right)$ \\
\hline
\end{tabular}

${ }^{a}$ For the conditions and analytical methods, see experimental section. The copolymers were prepared by polymerization in the presence of AMVN at $30^{\circ} \mathrm{C}$. ${ }^{\mathrm{b}} \alpha$ is the fraction of the weight loss in the decomposition step.
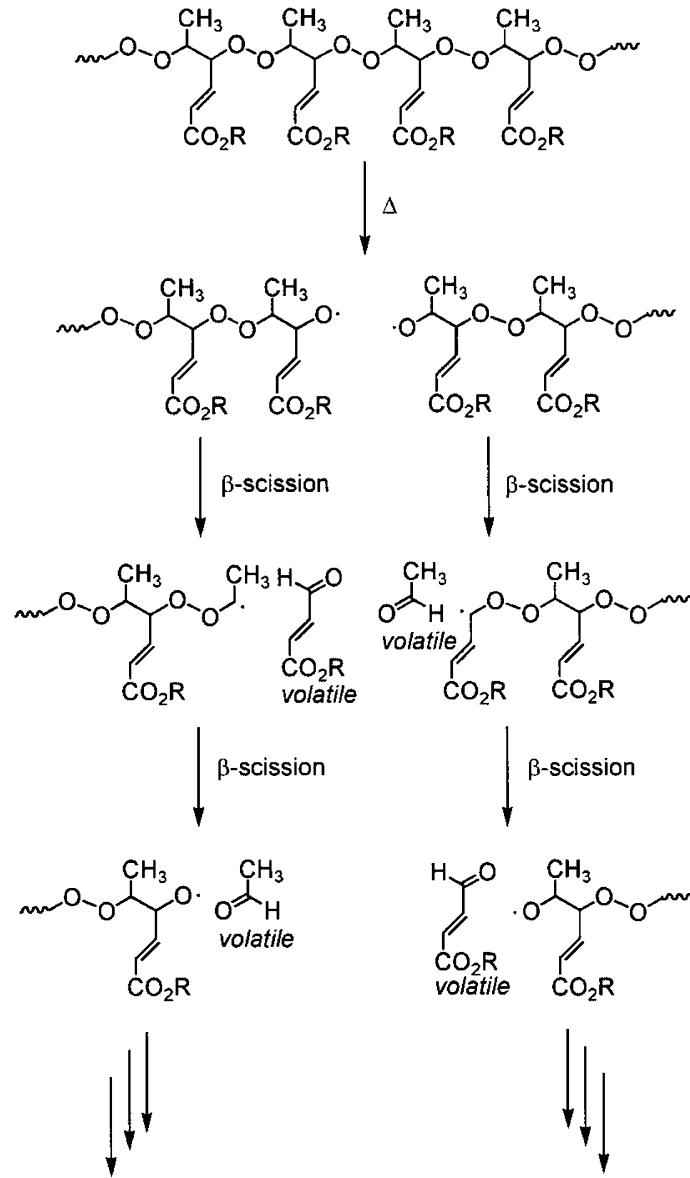

Scheme 5.

nism of PP-RS. First, the peroxy linkage of the copolymers is cleft upon heating and generates two peroxy radicals. One of them causes $\beta$-scission to produce a fumaraldehyde monoalkyl ester. The resulting carbon radical further undergoes $\beta$-scission and produces acetaldehyde. These two kinds of $\beta$-scissions are continuously repeated and result in the production of the two aldehydes. Another peroxy radical produced by the first chain cleavage also continues the decomposition in a similar mechanism. It has been confirmed by NMR spectroscopy that the thermal decomposition products of PP-MS as the volatile fraction are fumaraldehyde monomethyl ester and acetaldehyde. The $\mathrm{O}-\mathrm{O}$ bond scission of the polymer chain is an exothermic process, while the successive steps for the elimination of the aldehydes are assumed to be slightly endothermic. ${ }^{20}$ The observed $\Delta H_{\text {unit }}$ values indicate the summation of one bond scission (exothermic) and several times of $\beta$ scission (slightly endothermic) as the average value per polymer repeating unit. The heating value for the decomposition of PP-HD $\left(S^{\prime}=4.6 \mathrm{~V} \mathrm{~s} \mathrm{unit}^{-1}\right.$, which corresponds to $-262 \mathrm{~kJ}^{\text {unit }}{ }^{-1}$ of $\left.\Delta H_{\text {unit }}\right)$ was higher than those for PP-RS (Table III). This is well consistent with the incomplete 2,3 structure in the polymer chain of PPHD. The existence of 2,5 structure in the main chain hinders the depolymerization ( $\beta$-scission to eliminate aldehydes) in a radical chain mechanism and provides the high $\Delta H_{\text {unit }}$ value. In the TG analysis, PP-HD resulted in the rapid decomposition at a low temperature upon heating due to its highly alternating copolymer structure, although the repeating units include both the 2,3 and 2,5 structures.

We also carried out kinetic analysis of the TG data using several reported methods. The equations used for the analyses are shown in eq. 1-3. The results are summarized in Table IV.

$\log \beta+\left(0.4567 E_{\mathrm{a}} / R T\right)=$ const. $(\text { Ozawa method })^{47,48}$

$$
\begin{aligned}
\log \left(\beta / T_{\max }{ }^{2}\right)= & -\left(E_{\mathrm{a}} / 2.303 R T_{\max }\right)+\log C \\
& -\log \left(E_{\mathrm{a}} / R\right)(\text { Kissinger method })^{49,50}
\end{aligned}
$$

$$
\begin{array}{r}
\log \left\{-\ln (1-\alpha) / T^{2}\right\}=\log \left\{\left(C R / \beta E_{\mathrm{a}}\right)\left(1-2 R T / E_{\mathrm{a}}\right)\right\} \\
-\left(E_{\mathrm{a}} / 2.303 R T\right)(\text { Coates and Redfern method })^{51}
\end{array}
$$


Where $E_{\mathrm{a}}, R, T$, and $C$ are the overall activation energy for decomposition, the gas constant, the absolute temperature, and constants, respectively. The Ozawa method requires TG data collected at a different heating rate $\left(\beta=5,10,20,40\right.$, and $80^{\circ} \mathrm{C} \mathrm{min}^{-1}$ in this work). This method is a simple and convenient process without any limited reaction kinetics; therefore, it is applied to various types of reactions. Here, $\alpha$ is the fraction of the weight loss in a decomposition step, and is represented as follows,

$$
\alpha=\left(m_{\mathrm{t}}-m_{0}\right) /\left(m_{\infty}-m_{0}\right)
$$

where $m_{0}, m_{\mathrm{t}}$, and $m_{\infty}$ are the initial sample weight, the sample weight at a time $t$, and the sample weight when the decomposition is finished, respectively. For $\alpha=0.1$, we determine $T_{1}-T_{5}$ values at each $\beta$. When the logarithm of $\beta$ is plotted against $1 / T$, a linear relationship is obtained for each $\alpha$ value, as shown in Figure $4 \mathrm{a} . E_{a}$ is determined from the slope of the line. In this case, $E_{\mathrm{a}}$ is calculated to be $93.7,119,127$, and $134 \mathrm{~kJ} \mathrm{~mol}^{-1}$ for $\alpha$ of $0.1,0.3,0.5$, and 0.7 , respectively.

The Kissinger method, which is one of the most general procedures for a differential method, also requires TG data at different $\beta$ values. The $T_{\max }$ value was determined from the derivative TG (DTG) curves at each $\beta$. When $\log \left(\beta / T_{\max }^{2}\right)$ was plotted against $1 / T_{\max }$, a linear relationship provided an $E_{\mathrm{a}}$ value of $132 \mathrm{~kJ} \mathrm{~mol}^{-1}$ (Figure 4b).

According to the Coats and Redfern method (Figure $4 \mathrm{c}$ ), the $E_{\mathrm{a}}$ value is evaluated from a TG curve at a fixed heating rate. The plot of $\log \left\{-\ln (1-\alpha) / T^{2}\right\}$ against $1 / T$ is used for evaluating an $E_{\mathrm{a}}$ value. The slope was decided in a temperature region of 100 $160^{\circ} \mathrm{C}$, and therefrom $E_{\mathrm{a}}$ was determined to be $117 \mathrm{~kJ}$ $\mathrm{mol}^{-1}$. Coates and Redfern plots for the other PP-RS provided $E_{\mathrm{a}}$ of $125,143,106$, and $131 \mathrm{~kJ} \mathrm{~mol}^{-1}$ for PPES, PP-ODS, PP-TFES, and PP-HD, respectively, by the similar procedures.

The $E_{\mathrm{a}}$ values determined by several methods in this work are $94-143 \mathrm{~kJ} \mathrm{~mol}^{-1}$, being similar to or slightly smaller than those for various types of peroxide polymers reported in the literature; for example, $103-198 \mathrm{~kJ} \mathrm{~mol}^{-1}$ for the copolymers of oxygen with various vinyl monomers. In the Ozawa method, the $E_{\mathrm{a}}$ values are dependent on the $\alpha$ value, i.e., the initial stage of decomposition implies a lower $E_{\mathrm{a}}$ value. The Kissinger method includes $T_{\max }$ values, and the $E_{\mathrm{a}}$ value $\left(132 \mathrm{~kJ} \mathrm{~mol}^{-1}\right)$ is quite similar to the $E_{\mathrm{a}}$ values at a relatively higher $\alpha$ value in the Ozawa method $(\alpha=0.5-0.7)$. The Coates and Redfern method provides intermediate values. Thus, the experimental $E_{\mathrm{a}}$ values depend on the method and the $\alpha$ value used for the analysis. This suggests that the decomposition of

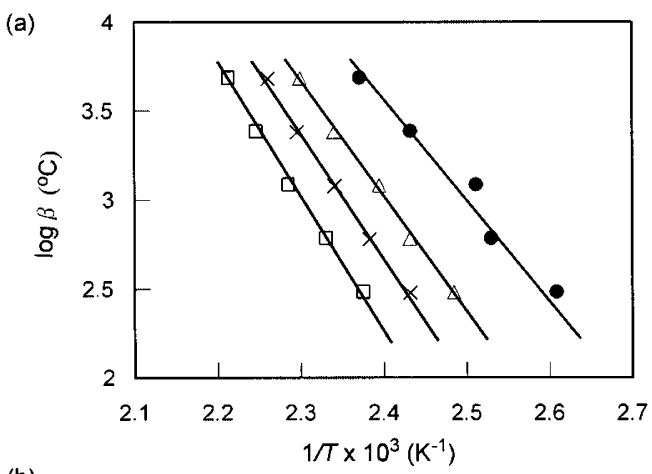

(b)
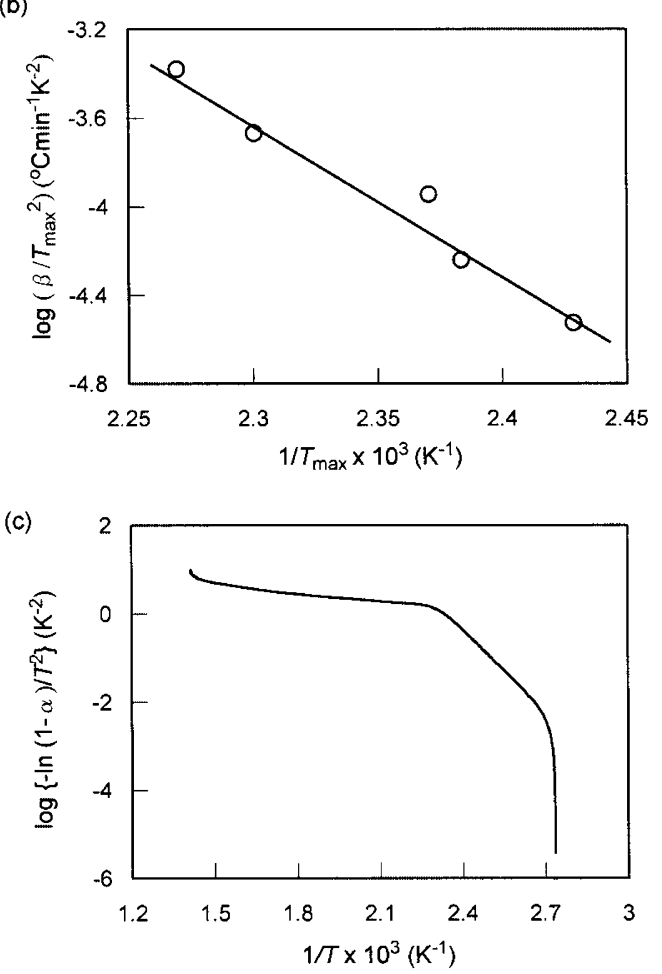

Figure 4. Kinetic analysis of TG curve for PP-MS. (a) Ozawa plots: $\alpha=0.1(\bigcirc), 0.3(\triangle), 0.5(\times)$, and $0.7(\square)$. A heating rate of $10^{\circ} \mathrm{C} \mathrm{min}{ }^{-1}$. (b) Kissinger plot. Heating rates of $5-80^{\circ} \mathrm{C} \mathrm{min}^{-1}$. (c) Coates and Redfern plot. A heating rate of $10^{\circ} \mathrm{C} \mathrm{min}^{-1}$.

the polymers implies several reactions, although we observe only weight loss as the index for decomposition during TG analysis.

\section{Kinetic Analysis for Isothermal Decomposition}

We have also investigated the isothermal decomposition behavior of PP-MS by both the TG and GPC methods to precisely evaluate the decomposition rate constants. A decrease in the molecular weight of a polymer due to the cleavage of a main chain is determined by GPC, while the weight loss of a polymer is monitored by TG. The weight loss of PP-MS was monitored under isothermal conditions in a temperature range of $80-120^{\circ} \mathrm{C}$. Figure $5 \mathrm{a}$ shows the results of the isothermal TG at each temperature as a function of the heating time.

When the step of the weight loss obeys first-order 
(a)

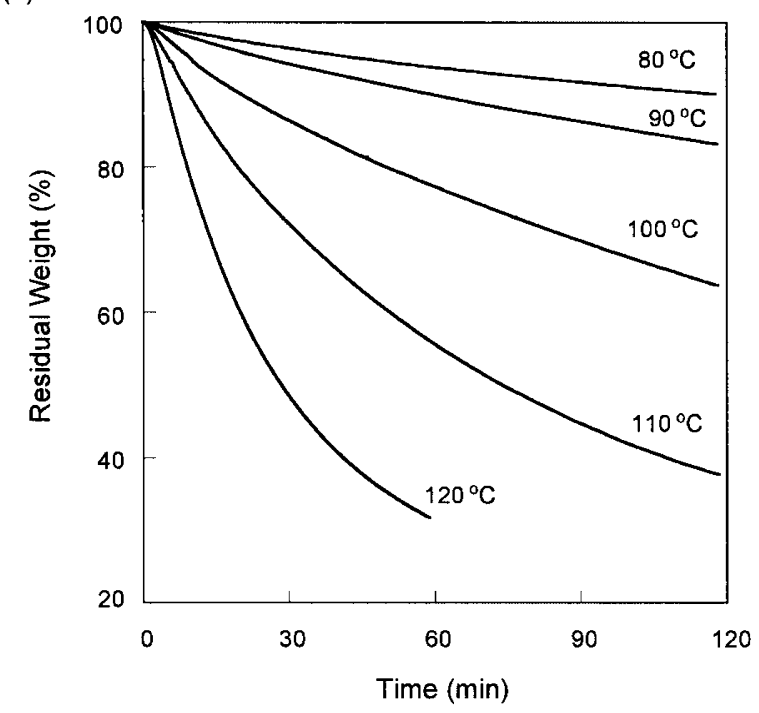

(b)

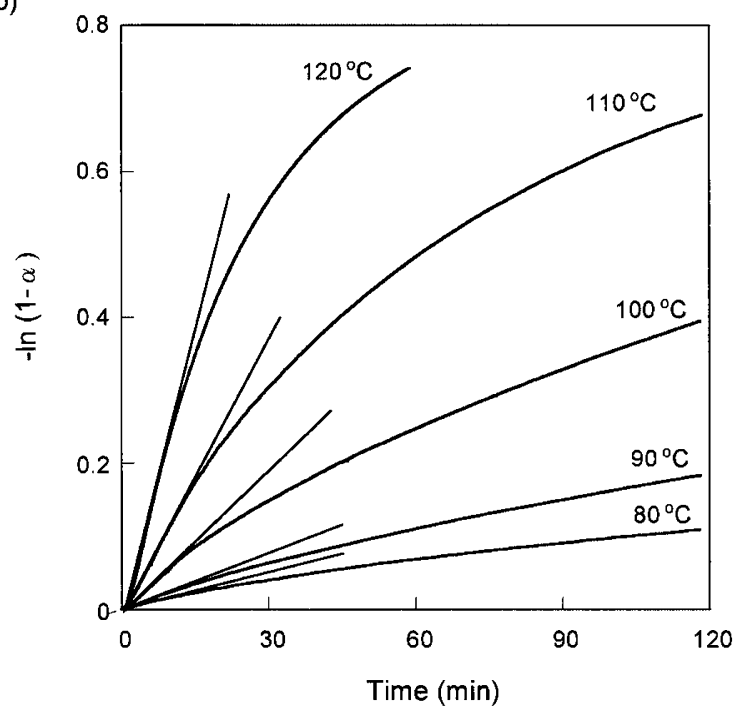

Figure 5. Isothermal decomposition of PP-MS monitored by TG in a temperature range of $80-120^{\circ} \mathrm{C}$ under nitrogen atmosphere. (a) TG curves. (b) Plots of $-\ln (1-\alpha)$ against the reaction time.

reaction, eq 4 is written by eq 5 .

$$
\mathrm{d} \alpha / \mathrm{d} t=k_{\mathrm{d}}(1-\alpha)
$$

where $k_{\mathrm{d}}$ is the thermal decomposition rate constant. Eq 5 is integrated as

$$
-\ln (1-\alpha)=k_{\mathrm{d}} t
$$

When logarithms of $1-\alpha$ are plotted as a function of $t$ at each temperature, the $k_{\mathrm{d}}$ values are determined from an initial slope of the curves in Figure $5 \mathrm{~b}$. The $k_{\mathrm{d}, \mathrm{TG}}$ value was determined to be $(0.28-5.09) \times 10^{-4} \mathrm{~s}^{-1}$ (Table V) from the data in the 0 to 1000 second ranges, because the plots were deviated from the linear relationship in the latter stage of the reactions.

Another thermal decomposition rate constant $\left(k_{\mathrm{d}, \mathrm{GPC}}\right)$ was evaluated with respect to the analysis based on the change in molecular weight by GPC.
Table V. Rate constants and activation energy for isothermal decomposition of PP-MS evaluated by TG and GPC methods ${ }^{\mathrm{a}}$

\begin{tabular}{ccc}
\hline Temp. $\left({ }^{\circ} \mathrm{C}\right)$ & $k_{\mathrm{d}, \mathrm{TG}} \times 10^{4}\left(\mathrm{~s}^{-1}\right)$ & $k_{\mathrm{d}, \mathrm{GPC}} \times 10^{4}\left(\mathrm{~s}^{-1}\right)$ \\
\hline 80 & 0.28 & 0.36 \\
90 & 0.39 & 1.09 \\
100 & 1.04 & 1.54 \\
110 & 2.23 & 2.99 \\
120 & 5.09 & 8.59 \\
$E_{\mathrm{a}}\left(\mathrm{kJ} \mathrm{mol}^{-1}\right)$ & 86.7 & 84.7 \\
$A$ & $1.53 \times 10^{16}$ & $1.31 \times 10^{16}$ \\
\hline
\end{tabular}

${ }^{\mathrm{a}}$ The copolymers were prepared by polymerization in the presence of AMVN at $30^{\circ} \mathrm{C}$. The decomposition was carried out at each temperature in a nitrogen or argon stream.

Figure 6a shows the decrease in the molecular weight of PP-MS upon heating at various temperatures (80$120^{\circ} \mathrm{C}$ ) in bulk under an argon atmosphere. A change in the molecular weight was evaluated as the relative value of the molecular weight of PP-MS $\left(M_{\mathrm{n}}\right)$ after heating to the parent molecular weight $\left(M_{\mathrm{n}, 0}\right)$, and plotted against the heating time at each temperature. The rate of the decrease in the molecular weight was accelerated as the temperature increased. From these results, the $k_{\mathrm{d}, \mathrm{GPC}}$ was determined as follows. When the main chain of a polymer with $M_{\mathrm{n}, 0}$ is cut off once per one polymer chain on the average upon heating, $M_{\mathrm{n}}$ is a half of the $M_{\mathrm{n}, 0}$ value. When cleavage occurs twice per one polymer chain on the average, $M_{\mathrm{n}}$ is one third of $M_{\mathrm{n}, 0}$. Similarly, when a polymer chain is cut off $n$ times per one polymer chain on the average, $M_{n}$ is represented as,

$$
M_{\mathrm{n}}=M_{\mathrm{n}, 0} /(n+1)
$$

This is changed into the following expression.

$$
n=\left(M_{\mathrm{n}, 0} / M_{\mathrm{n}}\right)-1
$$

When the values of $n$ are plotted as a function of the heating time, the slope of the curve results in the $k_{\mathrm{d}, \mathrm{GPC}}$ value at each temperature. The results are shown in Figure $6 \mathrm{~b}$. The plots gave an approximately linear relationship and the $k_{\mathrm{d}, \mathrm{GPC}}$ values were determined from the slopes, whose values were $(0.36-8.59) \times 10^{-4} \mathrm{~s}^{-1}$ in a temperature range of $80-120^{\circ} \mathrm{C}$ (Table $\mathrm{V}$ ).

As compared with two kinds of the $k_{\mathrm{d}}$ values, the $k_{\mathrm{d}, \mathrm{GPC}}$ values are slightly larger than $k_{\mathrm{d}, \mathrm{TG}}$. From the Arrhenius plots, the $E_{\mathrm{a}}$ values were determined to be 86.7 and $84.7 \mathrm{~kJ} \mathrm{~mol}^{-1}$ for the data by TG and GPC methods, respectively. The similar $k_{\mathrm{d}}$ and $E_{\mathrm{a}}$ values by the both suggest that peroxy linkages are cleft upon heating and simultaneously low-molecular and volatile fumaraldehyde monomethyl ester and acetaldehyde are formed through successive $\beta$-scissions at a comparable reaction rate. The $E_{\mathrm{a}}$ values for PP-RS determined in this work are much lower than those for low-molecular- 
(a)

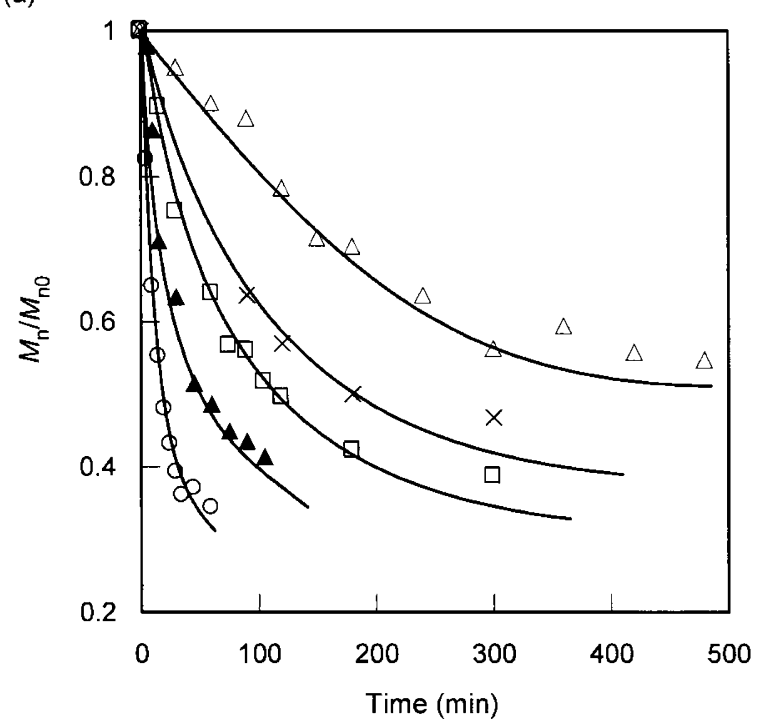

(b)

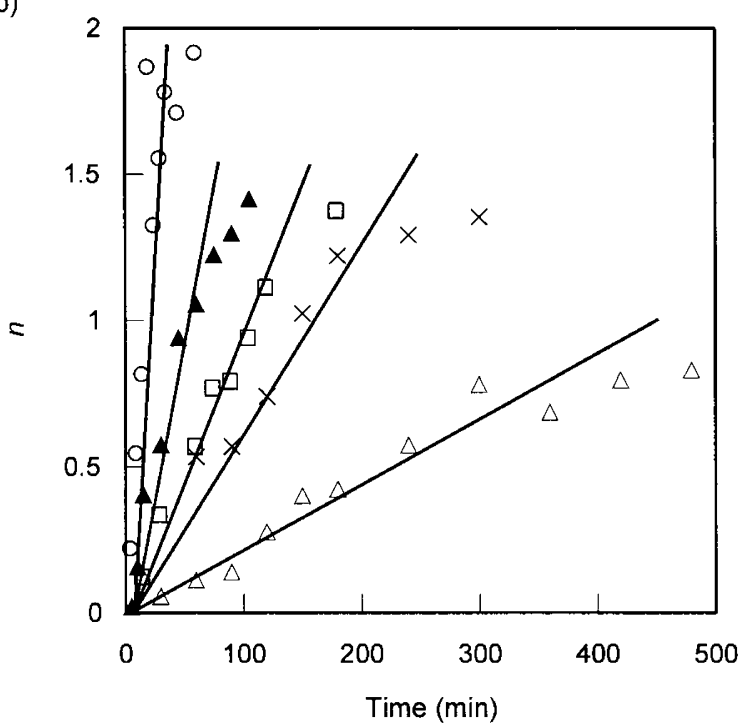

Figure 6. Isothermal decomposition of PP-MS monitored by GPC in a temperature range of $80-120^{\circ} \mathrm{C}$ under argon atmosphere. (a) Change in the relative molecular weight. (b) The number of bond scissions $(n)$ against the reaction time. $(\triangle) 80^{\circ} \mathrm{C},(\times) 90^{\circ} \mathrm{C}$, () $100^{\circ} \mathrm{C},(\mathbf{\Delta}) 110^{\circ} \mathrm{C}$, and $(\bigcirc) 120^{\circ} \mathrm{C}$.

weight organic peroxide, for example, lauroyl peroxide $\left(E_{\mathrm{a}}=125.3 \mathrm{~kJ} \mathrm{~mol}^{-1}, A=3.93 \times 10^{14}, 10 \mathrm{~h}\left(t_{1 / 2}\right)=\right.$ $\left.66^{\circ} \mathrm{C}\right)$, benzoyl peroxide $\left(E_{\mathrm{a}}=139.0 \mathrm{~kJ} \mathrm{~mol}^{-1}, A=\right.$ $\left.9.34 \times 10^{15}, 10 \mathrm{~h}\left(t_{1 / 2}\right)=78^{\circ} \mathrm{C}\right)$, and di-tert-butyl peroxide $\left(E_{\mathrm{a}}=152.7 \mathrm{~kJ} \mathrm{~mol}^{-1}, A=2.16 \times 10^{15}, 10 \mathrm{~h}\left(t_{2 / 1}\right)=\right.$ $\left.125^{\circ} \mathrm{C}\right) .{ }^{52}$ Here, $A$ and $10 \mathrm{~h}\left(t_{1 / 2}\right)$ are the frequency factor and the temperature for 10-h half-life, respectively. The absolute $k_{\mathrm{d}}$ value for PP-MS is similar to that for benzoyl peroxide; $k_{\mathrm{d}}$ is calculated as $1.15 \times 10^{-4}$, $2.58 \times 10^{-5}$, and $5.60 \times 10^{-8} \mathrm{~s}^{-1}$ at $80^{\circ} \mathrm{C}$ for lauroyl, benzoyl, and di-tert-butyl peroxides, respectively. The moderate decomposition rate of PP-RS is due to the fact that the frequency factors are not so large for the decomposition of PP-RS, possibly related to their polymeric peroxide structure, despite the low $E_{\mathrm{a}}$ values.
Actually, PP-RS can be treated without any special protection and technique during the preparation and isolation in a laboratory, unless they are contacted with any reducing agents or a metal. Of course, we have carefully carried out all the experiments for the synthesis and characterization on a small scale (see experimental). PP-RS obtained in this work are viscous liquid or tacky solid except PP-ODS due to their low $T_{\mathrm{g}}$ values and low molecular weights. The relative safety of the polymeric peroxides is one of the noteworthy features prior to low-molecular-weight peroxide molecules, especially crystalline solids such as benzoyl peroxide, which is sensitive to a shock, friction, and static electricity. Furthermore, the amount of heat during the decomposition may be controlled by the content of oxygen incorporated into the copolymers at the reduced partial pressure of oxygen for the practical use of these polymers.

\section{CONCLUSION}

We have reported a new type of radical alternating copolymerization of alkyl sorbates with oxygen to form degradable peroxide polymers in a convenient polymerization process. The polymeric peroxides (PP-RS) were readily prepared from several diene monomers by radical copolymerization in the presence of an azo initiator with the bubbling of oxygen or air. The alternating propagation of RS with oxygen successively occured due to the asymmetric structure of the sorbate monomers, resulting in the efficient synthesis of alternating copolymers with a 5,4 repeating structure. We have confirmed that the resulting copolymers have peroxy linkages in their main chain and readily decompose to produce radicals upon heating. The exclusive 5,4 propagation is important to determine the thermal decomposition properties of the alternating copolymers, because the existence of a 5,2 structure is not favored for efficient depolymerization. From the studies on the thermal decomposition kinetics and mechanism, it has been revealed that the obtained PP-RS decomposes exothermically in a nitrogen atmosphere, irrespective of the kind of the ester alkyl group; $T_{\text {init }}=$ $106.5-112.4^{\circ} \mathrm{C}$ and $T_{\max }=147.0-152.2^{\circ} \mathrm{C}$ by DTA. The thermal decomposition rate constants, $k_{\mathrm{d}, \mathrm{TG}}$ and $k_{\mathrm{d}, \mathrm{GPC}}$, were determined from two independent methods using the weight loss monitored by TG and the change in the molecular weight determined by the GPC measurement. The decomposition activation energy of PP-MS was determined to be $86.7 \mathrm{~kJ} \mathrm{~mol}^{-1}$ from the weight loss of the polymers and $84.7 \mathrm{~kJ} \mathrm{~mol}^{-1}$ from the molecular weight change of the polymers. We detected fumaraldehyde monoesters and acetaldehyde as 
low-molecular weight decomposition products, which were formed by the cleavage of peroxy linkages and the subsequent $\beta$-scission. The molecular weight of PP-RS obtained in this work was less than $10^{4}$, but our preliminary experiments have already revealed the fact that a bifunctional monomer provides degradable gels showing degradation temperature and properties similar to those of linear polymers. In the future, the design of a side chain structure will lead to new functional polymers and gels, for example, degradable hydrogels, which have great potential for a wide range of use in various fields of polymer chemistry and material science including adhesion, coating, environmental, and medicinal chemistry.

Acknowledgment. This work was financially supported by The Sumitomo Foundation.

\section{REFERENCES}

1. W. Schunabel, "Polymer Degradation: Principles and Practical Applications," Hanser, München, 1981.

2. G. Scott, Ed., "Degradable Polymers: Principles and Applications," 2nd ed, Chapman \& Hall, New York, N.Y., 1995.

3. G. Scott, "Polymers and the Environment," Royal Society of Chemistry, Manchester, 1999.

4. S. Kobayashi, J. Polym. Sci., Part A: Polym. Chem., 37, 3041 (1999).

5. K. Sudesh, H. Abe, and Y. Doi, Porg. Polym. Sci., 25, 1503 (2000).

6. S. Matsuzawa, Macromol. Biosci., 2, 105 (2002).

7. E. S. Stevens, "Green Plastics: An Introduction to the New Science of Biodegradable Plastics," Princeton University Press, Princeton, 2002.

8. T. Mukundan and K. Kishore, Prog. Polym. Sci., 15, 475 (1990).

9. F. A. Bovey and I. M. Kolthoff, J. Am. Chem. Soc., 69, 2143 (1947).

10. K. C. Smeltz and E. Dyer, J. Am. Chem. Soc., 74, 623 (1952).

11. G. V. Schulz and G. Henrici, Makromol. Chem., 18/19, 437 (1956).

12. A. A. Miller and F. R. Mayo, J. Am. Chem. Soc., 78, 1017 (1956).

13. G. A. Russell, J. Am. Chem. Soc., 78, 1035 (1956).

14. F. R. Mayo and A. A. Miller, J. Am. Chem. Soc., 80, 2480 (1958).

15. F. R. Mayo and A. A. Miller, J. Am. Chem. Soc., 80, 2493 (1958).

16. F. R. Mayo, J. Am. Chem. Soc., 80, 2497 (1958).

17. C. H. Bamford and P. R. Moris, Makromol. Chem., 87, 73 (1965).

18. A. Garton and M. H. George, J. Polym. Sci., Polym. Chem. Ed., 11, 2153 (1973).

19. M. Nukui, Y. Ohkatsu, and T. Tsuruta, Makromol. Chem., 182, 2209 (1981).
20. K. Kishore and K. Ravindran, Macromolecules, 15, 1638 (1982).

21. J. Jayaseharam and K. Kishore, J. Am. Chem. Soc., 120, 825 (1998).

22. A. K. Nanda and K. Kishore, Macromolecules, 34, 1558 (2001).

23. P. De and D. N. Sathyanarayana, Macromol. Chem. Phys., 203, 420 (2002).

24. T. Nakano, O. Nakagawa, T. Yabe, and Y. Okamoto, Macromolecules, 36, 1433 (2003).

25. H. Staudinger, Z. Angew. Chem., 35, 657 (1922).

26. H. Staudinger, Chem. Ber, 58B, 1075 (1925).

27. K. Kishore, S. Paramasivam, and T. E. Sandhya, Macromolecules, 29, 6973 (1996).

28. J. Jayaseharan and K. Kishore, Macromolecules, 30, 3858 (1997).

29. A. Matsumoto, Y. Ishizu, and K. Yokoi, Macromol. Chem. Phys., 199, 2511 (1998).

30. A. Matsumoto and H. Higashi, Macromolecules, 33, 1651 (2000).

31. W. Kerr, H. Gokusch, and A. Wolfram, Makromol. Chem., 3, 223 (1949).

32. H. Hock and F. Depke, Chem. Ber., 84, 349 (1951).

33. W. Kerr, A. R. Heinz, and J. Stallmann, Makromol. Chem., 16, 21 (1955).

34. B. R. Thakur, R. K. Singh, and S. S. Arya, Food Rev. Inter., 10, 71 (1994).

35. L. Pekkarinnen, Acta Chem. Scand., 26, 2367 (1972).

36. L. Dulog and K. Tsobanidis, Makromol. Chem., Rapid Commun., 2, 407 (1981).

37. Y. Kita and M. Matsugi, in "Radicals in Organic Synthesis," P. Renaud and M. P. Sibi, Eds., Wiley-VCH, Weinheim, 2001, Vol.1, p 1.

38. A. Matsumoto, T. Matsumura, and S. Aoki, Macromolecules, 29, 423 (1996).

39. A. Matsumoto, A. Horie, and T. Otsu, Makromol. Chem., Rapid Commun., 12, 681 (1991).

40. J. Brandrup, E. H. Immergut, and E. A. Grulke, Eds., "Polymer Handbook," 4th ed, John Wiley \& Sons, Inc., New York, N.Y., 1999.

41. J. A. Howard, K. U. Ingold, and M. Symonds, Can. J. Chem., 46, 1017 (1968).

42. G. A. Russell, in "Free Radicals," J. K. Kochi, Ed., Jonh Wiley \& Sons, Inc., New York, N.Y., 1973, Vol.1, p 295.

43. I. Flemming, "Frontier Orbitals and Organic Chemical Reactions," William Clowes \& Sons, London, 1976.

44. A. Matsumoto, Y. Oki, and T. Otsu, Polym. J., 23, 201 (1991).

45. N. A. Plate and V. P. Shibaev, Macromol. Rev., 8, 117 (1974).

46. K. Kishore and T. Mukundan, Nature, 324, 130 (1986).

47. T. Ozawa, Bull. Chem. Soc. Jpn., 38, 1881 (1965).

48. J. H. Flynn and L. A. Wall, J. Polym. Sci., B4, 323 (1966).

49. H. E. Kissinger, J. Res. Natl. Bur. Std., 57, 217 (1956).

50. H. E. Kissinger, Anal. Chem., 29, 1702 (1957).

51. A. W. Coats and J. P. Redfern, Nature, 201, 68 (1964).

52. G. Moad and D. H. Solomon, "The Chemistry of Free Radical Polymerization," Pergamon, Oxford, 1995. 